\title{
E-learning Practice at Medical Universities in Poland in the Perspective of the SARS-CoV-2 Pandemic
}

\author{
Piotr K. Leszczyński ${ }^{1}$, Magdalena Roszak ${ }^{2}$, Aneta Binkowska ${ }^{3}$, \\ Paweł Świniarski $^{4}$, Aleksandra Wilk ${ }^{5}$, Anna Charuta ${ }^{1}$, \\ Tamara Zacharuk ${ }^{6}$, Andrzej A. Kononowicz ${ }^{7}$
}

${ }^{1}$ Faculty of Medical Sciences and Health Sciences, Siedlce University of Natural Sciences and Humanities, Poland

2 Department of Computer Science and Statistics, Poznan University of Medical Sciences, Poland

3 Department of Emergency Medicine, Medical University of Warsaw, Poland

${ }^{4}$ Warsaw College of Rehabilitation, Poland

5 Department of Histology and Embryology, Pomeranian Medical University in Szczecin, Poland

${ }^{6}$ Faculty of Social Sciences, Siedlce University of Natural Sciences and Humanities, Poland

7 Department of Bioinformatics and Telemedicine, Jagiellonian University Medical College, Poland

\begin{abstract}
The epidemiological situation resulting from the SARS-CoV-2 pandemic caused the Polish universities to fully switch to distance education in March 2020. Medical e-learning has not yet been broadly implemented into the education process. Therefore, examples of successful e-learning implementations or the organization of the process of medical e-learning offer a valuable source of knowledge today, which is needed immediately. The article presents e-learning practices at the Polish medical universities during the SARS-CoV-2 epidemic during the period from March to September 2020, covering seven universities in Poland that offer medical and health studies. The organization and implementation of e-learning classes is presented, including knowledge evaluation practices, providing example decisions issued by university rectors, on which the teaching process was based. A detailed presentation of the schools' organizational units or workgroups that played an important role in the process of coordination of measures supporting e-education is also included. The article also presents a description of the software applications, utilities, and services used at the schools in the course of the process of online education. Below are some examples of specific such implementations in selected university courses.
\end{abstract}




\section{Introduction}

The epidemiological situation resulting from the SARS-CoV-2 pandemic caused the Polish universities to fully switch to education based on elearning technologies, virtual reality, and online communication via the Internet in March 2020. It was a major challenge for medical universities to transition immediately to an e-learning-only system.

Medical universities in Poland had been offering e-learning classes before the pandemic, yet only few of them offered subjects taught exclusively online. For reason of its unique features, medical training is mainly offered as a blended-learning model (part A and part B). Thus, part A) of education is delivered on-site, in real time, in such university buildings as seminar rooms, laboratories, or clinics located at university hospitals. Part B) takes place online, typically in an asynchronous mode, with the use of an e-learning portal (Arroyo-Morales et al., 2012; Swift et al., 2016).

IT departments or e-learning centers exist at medical universities, employing professionals with appropriate competences in the area of eeducation; the universities also have adequate hardware infrastructure. Nevertheless, medical e-learning has not yet been broadly implemented into the process of education (Roszak, 2019). The state of epidemic made it necessary for academic teachers to improve their professional qualifications, particularly to work with e-learning tools and specialist utilities, and to contribute to the building of online learners' communities. Academic teachers working at medical universities have to regularly advance their IT competences and to be trained in online class design (Roszak et al., 2019).

Examples of successful e-learning implementations or the organization of medical e-learning processes offer a valuable source of knowledge today, which is needed immediately. The accomplished techniques and scenarios can be helpful for organizational units and teachers from universities with different profiles. Due to the state of epidemic, sharing experiences is very important, and the time for independent examination and testing is significantly shorter than it was before the epidemic. Hence, this paper is a source of data supporting and aiding the work on e-learning on the education market in Poland.

The article presents the e-learning practices at Polish medical universities during the SARS-CoV-2 epidemic in the period from March to September 2020, covering six universities in Poland offering medical and health studies. These are the following schools: Siedlce University of Natural Sciences and Humanities, Poznan University of Medical Sciences, Medical University of Warsaw, Warsaw College of Rehabilitation, Pomeranian Medical 
University in Szczecin, and Jagiellonian University Medical College. The article presents the organization and implementation of e-learning classes, including knowledge evaluation practices, presenting example decisions issued by university rectors, on which the teaching process was based. A detailed presentation of the schools' organizational units or workgroups that played an important role in the process of coordination of measures supporting e-education is also included. Software applications, utilities, and services used at the schools in the course of the online education process are also described. Below are some examples of specific such implementations in selected university courses. The conclusions and suggestions, provided as feedback of those activities, generate further work to be performed. These are the challenges to be faced by the academic communities at medical schools in the next academic year 2020/2021 and in subsequent years of e-learning activity.

The various phrases encountered in literature such as e-education, distance learning, distance education, e-learning, etc., represent the same education process, with the exception of certain key functions. In this paper, such phrases are used interchangeably.

\section{Poznan University of Medical Sciences - Comparison of Exam Results Before and During the Pandemic}

Changes were implemented in the education process at the Poznan University of Medical Sciences from March to September 2020 in accordance with the rulings passed by the University Authorities in response to the rapidly changing epidemiological situation in Poland. These rulings concerned the course delivery methods, including methods of providing education at university clinics for students in the final years of their studies, or methods of electronic knowledge evaluation. The first decision of this kind was passed on 12 March, 2020.

A general organizational unit had been operating at the school for 9 years, responsible for coordination and organization of exams via the e-learning portal. New e-learning courses began to appear on the university's e-learning portal, while the Microsoft Teams service was implemented for real-time meetings. The volume of material in the school's knowledge repository increased, made available to all teachers, to be used immediately for e-courses without any specific pre-existing e-learning competences. The school has its own recording studio, launched in 2019 for the purpose of creating multimedia resources, and a medical simulation center where online 
courses with simulated patients began. During the pandemic, the volume of tasks and work involving e-learning support units increased significantly, similarly to all other universities in Poland. The number of teaching and assistant staff increased as well.

Moreover, teachers would quickly deploy other utilities and applications at their courses (such as Socrative), or use educational resources available from third party platforms, such as Incision, MEDtube, or ClinicalKey Student.

Those departments that had already had some experience with the delivery of e-learning or blended-learning courses had no problems with transitioning to full online studies, implementing the solutions at other courses accordingly. Teachers with no prior experience with e-learning tried to enter the e-education world quickly, according to their individual capabilities and the characteristic features of their courses. To help them achieve this goal, the school not only offered individual consultation or training, but also Education Newsletters for Hard Times, to show examples of earlier online courses and encourage others to pursue similar activities. Teachers participated readily in the training offered by the school in the Use of an Education Platform in Creating E-learning Courses.

An analysis comparing the knowledge evaluation processes in preclinical courses taught entirely in the form of e-learning (during the pan-

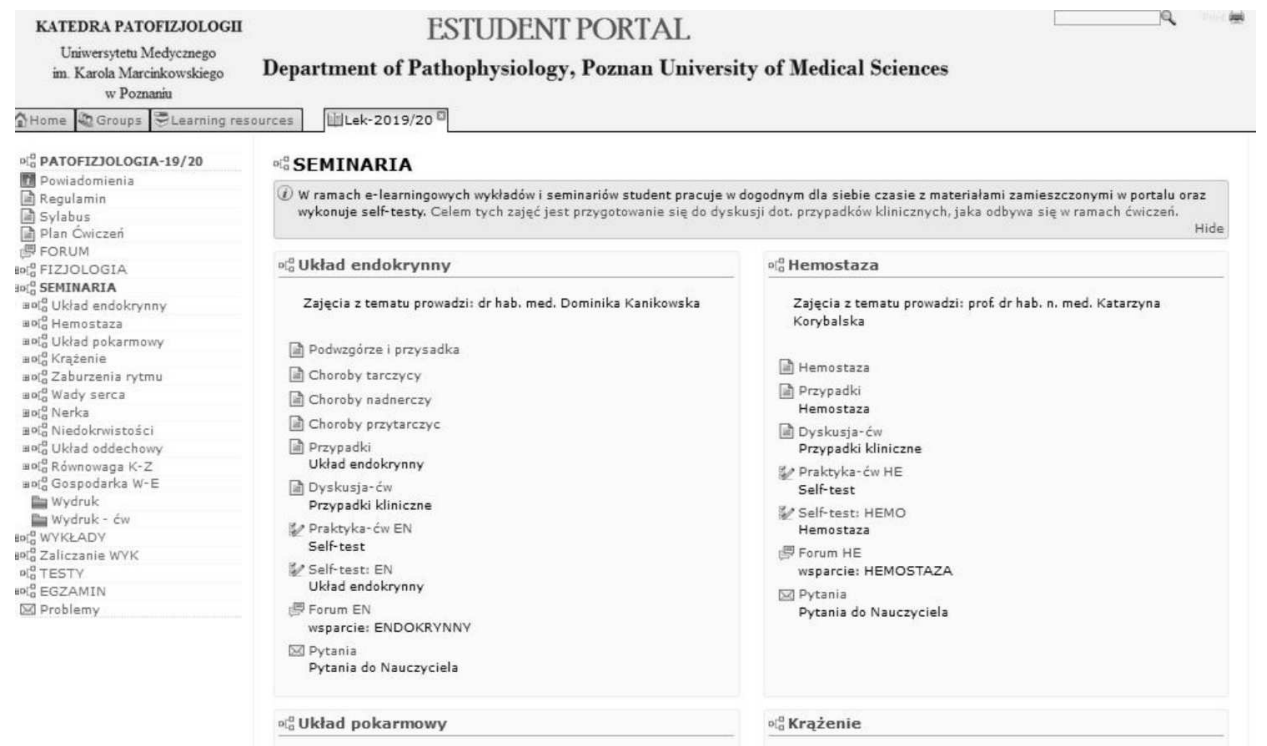

Figure 1. E-learning course in Pathophysiology for year 2 of Medicine studies 
demic) with courses provided in the blended-learning scheme (before the epidemic) in pathophysiology has also been performed. The results demonstrated similar educational effects, regardless of the course format; in some topics, the results achieved by students who studied them on an e-learning basis were higher than those achieved in traditional class groups (Figure 1).

In the academic year 2020/2021, courses will be offered in a hybrid scheme. Practical classes are planned on site, which is particularly important in the case of clinical subjects, although online practice is also acceptable upon the Dean's consent. Lectures, however, will be delivered online only. The online option is also recommended for seminars. The actual development of the epidemiological situation in Poland will determine whether e-learning will be re-launched again at all courses, or the hybrid scheme will be found appropriate.

\section{Siedlce University of Natural Sciences and Humanities- Interactivity}

The Siedlce University of Natural Sciences and Humanities (UPH) is certified to offer university degree education in fields of study such as nursing, emergency medical rescue, and dietetics. These courses of study are offered as the practical (vocational) profile at the Faculty of Medical Sciences and Health Sciences. As early as on March 13, pursuant to the Decision of the Rector of UPH, an online education organization workgroup was established. It was composed of more than ten members, including representatives of the Computer Network Management Center and the IT Applications and Systems Section. Five days later it was announced that as of 23 March, 2020, an online study scheme was implemented at the University, with the use of the G Suite for Schools and Universities provided by Google Inc. (Zarządzenie Rektora Uniwerytetu Przyrodniczo-Humianistycznego, 2020, Marzec 16). The UPH University Computer Network Management Center created individual e-mail accounts for master's and doctoral degree students within the G Suite service. The offices of the individual Departments were required to create calendars with class schedules in G Suite. Meet was used as a direct communication tool (online meetings).

Academic teachers conducted their classes according to their respective class schedules, with the option of sending additional teaching resources to students. Another option was the use of an external IRDIM platform based on the Moodle environment (www.irdim.net), which was an extension of the courses taught synchronously on Meet. 
Access to education courses was personalized for the particular fields of study. The platform administrator assigned the course author status to teachers, so that they were able to upload their teaching resources (text and multimedia files) within an e-learning course.

On 1 June, 2020, pursuant to the Regulation of the Minister of Science and Higher Education (Rozporządzenie MNiSW, 2020), the Rector of UPH passed the Decision no. 80/2020 concerning the organization of vocational practice training during the summer semester of the academic year 2019/2020 (Zarządzenie Rektora Uniwerytetu PrzyrodniczoHumianistycznego, 2020, Czerwiec 1). During the academic year 2019/2020, students of the nursing and emergency medical rescue departments could obtain a maximum of $40 \%$ ECTS points defined for the respective classes in the study programme for online courses. Moreover, in this case, the distance teaching tools implemented beforehand were found to be useful in giving students an opportunity to complete their vocational practice training requirements. Training supervisors offered such options as virtual walks around medical facilities, demonstrating the equipment and functioning of the graduates' future workplaces. A course teacher was using a tablet for live streaming with comments on the use of the presented equipment and rooms. Students were able to ask questions in real-time and the questions were answered on the spot in the synchronization mode. After the end of the demonstration sequence, students were given time to ask for returning to a room or piece of equipment they found particularly interesting. The course teacher could then use other camera points of view, as much as possible, so as to deliver a full representation of the specific facility or room. The practical training introduction narrative and the live video streaming option received positive feedback from students, as a good opportunity to become acquainted with the topography and the functioning of medical equipment, as well as the applicable health and safety principles. As soon as students are able to return to medical facilities again, the time-consuming induction procedure can be disregarded, which will save the time needed for the actual performance of medical procedures.

Interactivity. With the e-learning platform, users were able to utilize certain interactive tools which are identified in literature as efficient teaching forms for medical fields of study (Sobolewska \& Pinet-Peralta, 2019). The characteristics of work in the healthcare system imply the necessity to seek and implement advanced, effective teaching techniques, which would additionally foster the users' self-confidence (Boczkowska et al., 2018; Sowan et al., 2014). 
E-learning Practice at Medical Universities in Poland in the Perspective...

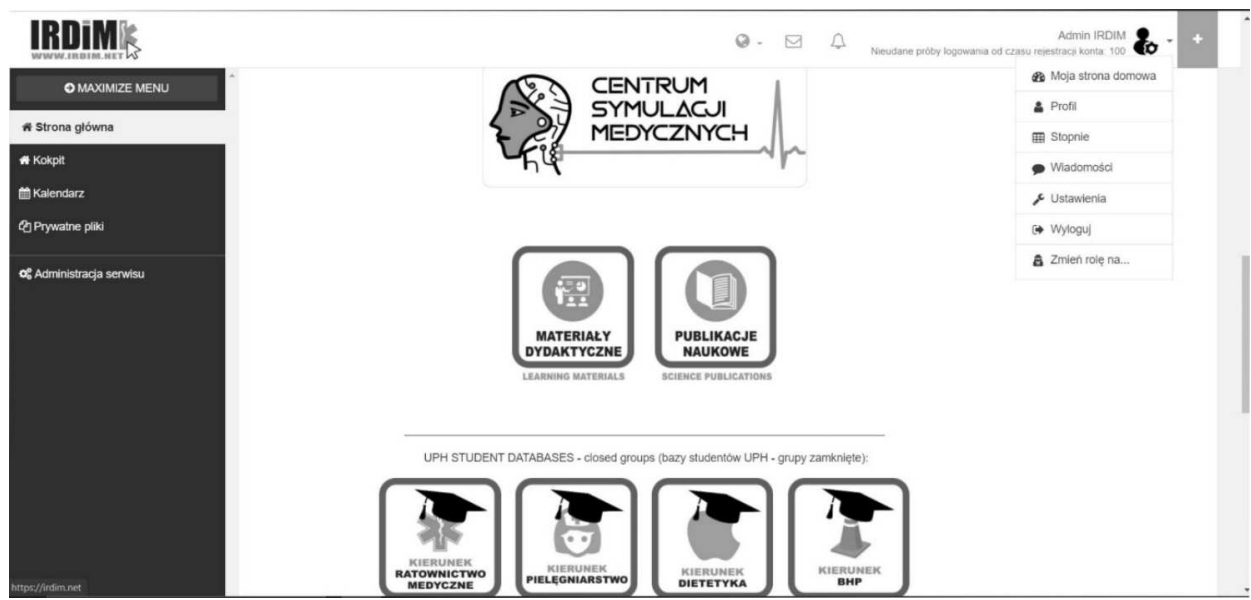

Figure 2. IRDIM platform interface

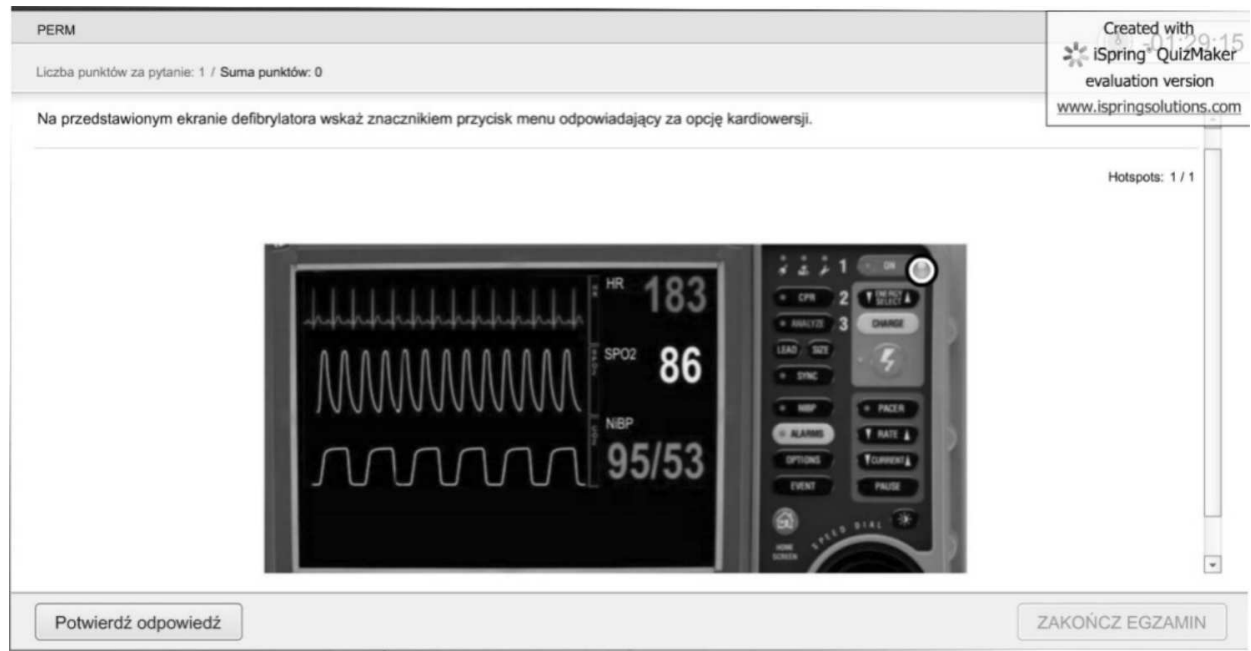

Figure 3. Use of virtual medical equipment online

Students checked their knowledge in an interactive application on the IRDIM (Figure 2) by solving cascade problems, e.g. concerning the use of virtual medical equipment (Figure 3). Event scenarios were provided to develop quick decision-making and non-technical skills (NTS) (Porter et al., 2018). Selected medical procedures such as heart tone auscultation, chest compression layout in a newborn, or medical triage in mass incidents were implemented in a similar manner (Wejnarski et al., 2018). Before the exam- 
ination session, students were given self-check opportunities, i.e. by solving interactive tests within a set time limit.

The future. The winter semester of the academic year 2020/2021 is still an uncertain period in terms of the development of the epidemiological situation in Poland. Both students and teachers hope that the university education system will not be locked down again. According to the present assumptions, reopening of classroom education is being prepared for those subjects/modules/courses which cannot be provided fully online. The experience of the beginning of the year 2020 and the developed e-learning solutions will certainly offer great support during the lectures in the new academic year.

The challenge. At the moment, the UPH Siedlce Medical Simulation Center development project is pending, which envisages advanced teaching solutions for medical faculties. High fidelity simulators, extended debriefing technologies, and virtual reality will make it possible to hold academic courses and vocational training in a highly realistic environment, in compliance with the applicable sanitary and epidemiological rules.

Conclusions and suggestions. The key issue for medical faculties is the inability to perform manual tasks in an online learning scheme, as well as the lack of contact with live patients. The practical study profile requires the appropriate minimum threshold of hours completed in future workplace environments. Own experience indicates that students in the initial years of their studies (in such fields as emergency medical rescue or nursing) will find out whether or not they have chosen the right profession for themselves only after completing their first vocational practice training. This opportunity is no longer available to them due to the pandemic restrictions (Mitura, 2020). Students in their final years have gathered more experience gathered and are familiar with the characteristics of the hospital or ambulance environment; therefore, they would find it easier during e-learning classes to imagine the actual conditions for performing their jobs. In this perspective, distance education is insufficient, even with the advanced multimedia solutions.

At the moment, no problems among UPH University teachers occur concerning system operation or teaching online classes. With assistance in the form of remote courses for software users and the requisite hardware availability, curricula could be covered in an optimized manner. There are incidents, however, connected with technical issues experienced by students who (particularly at the outset of the distance education implementation 
process) had problems with setting up a connection, camera, and/or microphone use. However, these problems were systematically resolved through email communication (students have their e-mail accounts set up by the university).

As conclusions for the subsequent academic year are drawn, the university can certainly consider itself much better prepared for the possible return to distance education than in March. The work started on new solutions in modern education has continued since, and will certainly deliver inspiring results.

\section{Medical University of Warsaw - Extensive Use of an E-learning Portal}

Preparing for distance education work. E-learning at the Medical University of Warsaw (MUW) is one of the available course teaching forms. The education platform is available in Polish as well as in the English language version for international students. E-class is an education session involving distance learning methods and techniques. Every E-class hour corresponds to 1 hour included in the teachers' working hours limit (1:1 equivalence), and students receive ECTS credits for E-classes. Both obligatory and optional courses can be taught in this form. Such courses are proposed at all the faculties and courses of study. E-classes at MUW can take place in various forms, such as:

- fully online learning (via the Internet);

- blended learning, i.e. a combination of traditional education in direct student-teacher contact and e-learning, in any proportion.

E-classes are produced in professional, specially adapted rooms on the MUW site. The e-learning platform used throughout the university is based on Moodle and available for all members of the academic community (e-learning.wum.edu.pl). It is also used for e-learning courses and training for the university staff. The sign-up system is based on the university's user authentication system (Figure 4).

Another function of the e-learning platform is an education support tool for activities offered to learners at traditional courses, with uploaded learning materials, tasks to complete, tests, and management of the process of final paper/project submission. Student organizations can also use the platform as a sharing space for various resources (such as repositories, presentations, case studies, videos, index cards, etc.), tasks to complete, tests, or organizational documents. 


\section{Uczelniany kurs e-learningowy}

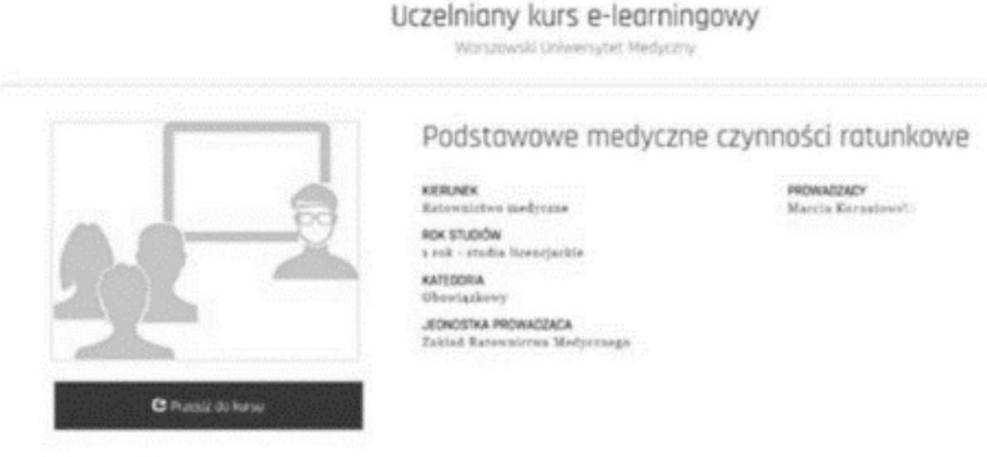

Strzeszczenie
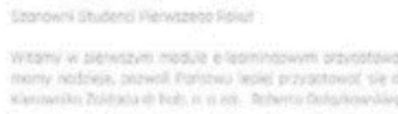

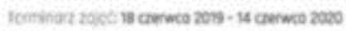

Figure 4. E-learning course at the Medical University of Warsaw

E-learning offers full distance learning management options with communication and interactive tasks for students. Students can have full or restricted access to a subject, where the latter can be gradually opened after passing the consecutive learning stages. The University's Education Quality and Innovation Bureau, with the support from the IT Division and the University E-Learning Workgroup, are responsible for platform management, delivery and development.

The time of pandemic is changing the universities. As of March 2020, all contact courses (on-site courses) with students of all the faculties at MUW were suspended, pursuant to the Rector's Decision of 12 March, 2020 (Zarządzenie Rektora Warszawskiego Uniwersytetu Medycznego, 2020, Marzec 12). All the lectures and seminars were moved to the e-learning portal. This decision was later amended, in response to the current pandemic conditions. A Coronavirus Hazard Workgroup was established at the University (Zarządzenie Rektora Warszawskiego Uniwersytetu Medycznego, 2020a, Marzec 13; 2020b, Marzec 13; 2020, Marzec 23; 2020, Czerwiec 1; 2020, Lipiec 6; 2020, Lipiec 10). The work performed by the group was essential for the distance learning practice, as it was responsible for ongoing course planning for students. Pursuant to the Rector's 
Decision of 20 August, 2020 (Zarządzenie Rektora Warszawskiego Uniwersytetu Medycznego, 2020, Sierpień 20; 2020, Sierpień 26; 2020, Wrzesień 3), most courses will be taught in the e-learning form; contact form will only remain for practical classes and those subjects which require onsite presence.

The winter semester of the academic year 2020/2021 is still an uncertain period in terms of the development of the epidemiological situation in Poland. At the moment, MUW teachers have time to prepare their elearning classes and select those which have to be held in the contact form, with full safety assurance for the students, patients, and teachers. New forms of passing interim and vacation training requirements applicable to students of medicine, nursing, obstetrics, and emergency medical rescue are being considered. All written exams took place online, via the e-learning platform. Only selected practice exams were held online or on-site, in compliance with all the applicable epidemiological restrictions. Both students and teachers hope that the university education system will not be locked down again. In any case, the experience of the last six months and the e-learning solutions developed at the university will certainly offer great support during courses in the upcoming academic year.

At the moment, classrooms are being prepared for real-time teaching of some online courses (synchronous mode). In this way, students will have an opportunity for contact during class, in real-time. Moreover, an optimum solution is being sought for student-patient contact and professional training.

The foundation of learning for a healthcare professional are practice and patient contact - the challenge. A crucial issue for medical faculties is the inability to perform manual tasks in an online learning scheme, as well as the lack of contact with live patients. During their medical studies, students learn certain medical procedures, such options not yet being available through e-learning. In many interviews, MUW teachers emphasized that the foundation of learning for a healthcare professional is practice and contact with patients. The pending legislation concerning university studies should take the specific character of medical schools into account. The restrictions existing in extraordinary circumstances such as a pandemic should involve more flexibility in the choice of forms of education. Students who have undergone practical training and had contact with patients in the course of their education feel better prepared for performing their jobs than those who have not been given these opportunities because of the pandemic. 
At the moment, MUW teachers do not report any issues related to the preparation of online classes; they have access to appropriate supporting utilities. If necessary, each teacher can make use of ready-made online training or consultation with the Education Quality and Innovation Division. They have free-of-charge access to the Office 2016 suite for staff and students and options for a mobile application available on the e-learning platform. The only problems occurring now are those concerning the quality of connection in large groups of students taking part in real-time online meetings. All lectures and most seminars are scheduled in asynchronous form, where students can access a selected session through the e-learning platform at any time of their choice.

In conclusion, MUW makes efforts to be prepared for the upcoming academic year 2020/2021 as well as possible, to face all changes and future restrictions, while maintaining the quality of education offered to students.

\section{Synchronous Work and Its Verification at the College of Rehabilitation}

Preparation to online learning. The Warsaw College of Rehabilitation (WCR) offers the following courses of studies: physiotherapy, emergency medical rescue, dietetics, medical psychology, and post-graduate studies. With Moodle, the education platform available across the school, lectures are delivered with the use of diverse resources supporting the process of covering the syllabuses. The Rector's Decision of 11 March, 2020 required WCR teachers to prepare and offer learning materials in electronic format as soon as possible, covering the planned syllabuses. Webinars could also be created within a course framework, offered through LiveWebinar. This type of solution gives a wide range of options of user interaction (audio, video, chat, surveys, tests, etc.) (Zarządzenie Rektora Wyższej Szkoły Rehabilitacji, 2020, Marzec 11).

Use of the Office 365 suite. Since 1 April, 2020, the School has been using the MS Office 365 Suite for online teaching, while courses are delivered via the Teams platform. An account has been set up for every teacher and every student, through which the course of study is followed.

Teams of students for each individual year were set up in the Teams utility. For Emergency Medical Rescue, every subject is a team, where the teacher is the administrator who has the requisite management tools. The teacher can create workgroups, engage in non-verbal communication, or cre- 
ate online courses for specific teams. Online Teams meetings give the teacher an opportunity to convey knowledge by uploading presentations, videos, or their own computer screens, at the same time discussing the respective topic. Student-teacher interaction is thus fully maintained. Another option available for teachers in Teams is to make certain materials available to a personalized group of students.

Courses were delivered on the basis of the existing syllabus matrix, similarly to traditional (on-site) learning. The teacher would connect to a specific team via Teams, in accordance with the course schedule. The calendar functionality in Teams provides information for students about the courses they are expected to attend.

Students' knowledge was verified through creating test forms in Forms from the Office 365 suite (Figure 5). The Forms tests have extensive customization options. The teacher sets the test date and time; as soon as a student confirms and sends in their form, they receive a report with their results, making the checking process much easier and faster. In accordance with the WCR Rector's Decision of 27 May, 2020, all exams were held using MS Office 365 solutions. To complete the examination session properly, technology-based verification of the principles of learning outcomes were implemented (Zarządzenie Rektora Wyższej Szkoły Rehabilitacji, 2020, Maj 27).

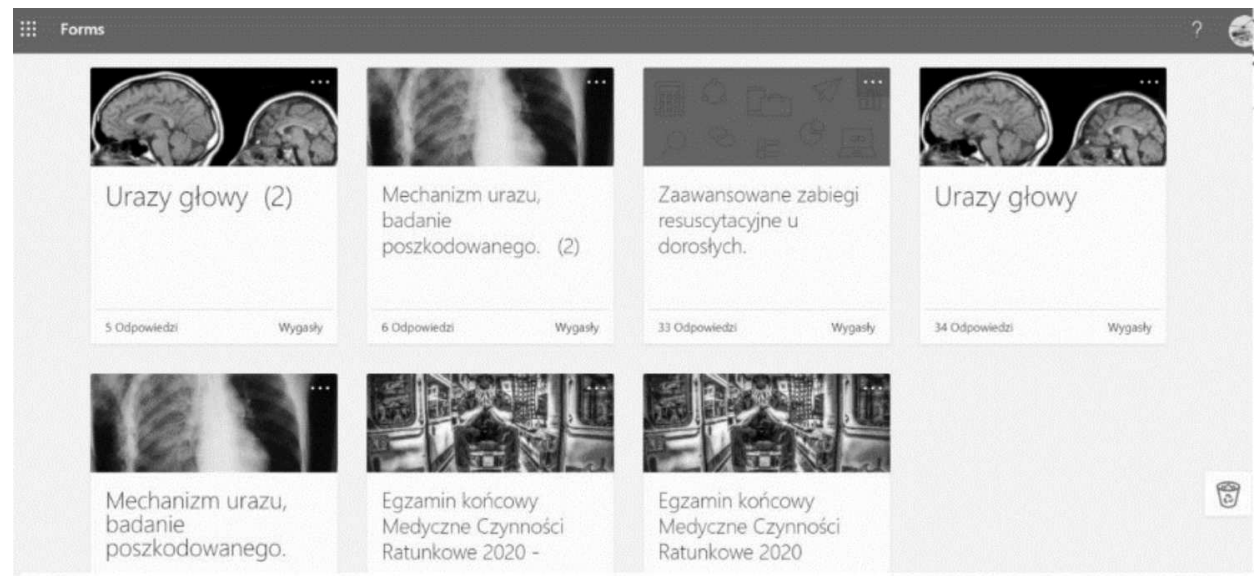

Figure 5. Tests in Forms from the Office 365 suite

In accordance with Article 76a of the Act of 20 July, 2018 - Higher Education and Study Law (consolidated text: Journal of Laws of 2020, item 85, as amended), a university can organize verification of the learning outcomes specified in the study syllabus, particularly through final projects and ex- 
ams closing specific courses, as well as final exams outside the university's premises or branch, with the use of information technologies that ensure continuous control and registration of the exam progress. The learning outcomes defined in the syllabuses for the courses of study offered at WCR are verified in accordance with the Study Rules, taking the following principles into account:

1. IT technology-based verification of learning outcomes with guaranteed online control (online exam) takes place with the use of MS Office 365 utilities ("Zasady weryfikacji", 2020).

2. The form of an online exam should be consistent with the methods of verification of learning outcomes defined in the course syllabus.

Organization of an online exam. The examiner presents a proposed online exam date to the Study Planning Department at least 10 days before the scheduled exam date, and the Department confirms that date or sets another date, in coordination with the School IT Expert. The examiner decides whether the online exam will be recorded. This decision is communicated to the Study Planning Department and the IT Department that ensures online control and recording.

The examiner informs the students of the exam date through the Virtual Dean's Office (it is recommended that other communication channels be used simultaneously, e.g. MS Teams class group). If the examiner decides that the online exam will be recorded, students are not allowed to switch off their microphones and/or cameras during that exam. Due to the limitations of MS Office utilities, where only 9 persons can be displayed on the screen during a videoconference, the examiner should randomly switch between student views to verify whether or not they are working on their own.

Training. Professional training at the Emergency Medical Rescue faculty was provided through virtual tours. A teacher would create an event in Teams and connect online (videoconference) to the specific workgroup, discussing such matters as ambulance equipment, or intensive care workstations. Students were able to learn the details of working at every workstation. At the moment, a medical simulation room is being built, with high fidelity mannequins. With this teaching method, the syllabus requirements will be achieved more effectively.

Conclusions for online education during the pandemic at the College of Rehabilitation. Below are the conclusions based on the courses already taught online: 
1. Following the implementation of the Office 365 platform, most teachers delivered their courses as webinars on Teams.

2. The vast majority of meetings for Emergency Medical Rescue students took place as webinars, according to the course schedule.

3. Teachers responsible for practical training reported the issue of not being able to fully cover the syllabus. Presentations, instruction videos, or demonstrations of medical operations cannot replace practice on mannequins and simulators, with the use of medical equipment.

4. Courses were graded in two forms: on the basis of interim grades for papers/projects/essays sent during the course, or through Forms. All exams took place in Forms and proceeded without any objections. However, despite the requirement to have a camera on, and even though students declare to be doing their work by themselves, it is not possible to fully control their work.

5. Forms can be the perfect tool for the evaluation of students' knowledge during on-site classes, on their own mobile devices. Results are known immediately after solving a test. In this case, the course teacher controls the student's progress.

6. Online consultation is a very attractive solution. Teachers were adjusting their schedules in a flexible way to the needs of students working different shifts. Consultation hours were set at different times of day, including late at night, both on working days and on weekends. The communication option most commonly suggested by teachers was online consultation on Teams (preferred and often used by students), or e-mail communication.

7. As only a limited number of students can be seen by the teacher at the same time (system limitations), it is not possible to verify whether or not they are actually taking part in the online meeting. The absence of interaction strengthens the impression that students have opened their application but are not present physically. A solution to this issue could be a mandatory end-of-meeting test, which would also constitute the attendance list. With some lectures delivered online, some burden is removed from strained class schedules.

8. Because of the lack of access rights to buildings/facilities, practical training for third students of Emergency Medical Rescue was provided as an online course, with students' own work and a final test. Training for students of the other years of study was postponed.

9. The MS Office 365 suite offers extensive online teaching options. WCR uses this method as the primary lecture model. Practical training involving the use of specialist equipment will still take place on site, with major safety restrictions. 
Piotr K. Leszczyński et al.

\section{Digitization of Histological Preparations and ITest Facilitate Online Courses at the Pomeranian Medical University in Szczecin}

During the pandemic, academic teachers at the Pomeranian Medical University in Szczecin (PMU) had a choice between the system utilities available, to offer an optimized environment for teaching online courses to students. These included Microsoft Office 365 (mainly MS Teams) as a videoconferencing tool and/or for delivering lectures, seminars and classes in real time online, or for recording lectures. Moodle s the e-learning platform used for uploading learning materials. At PUM, Moodle is integrated with the Virtual Dean's office system, streamlining the work of academic teachers and office procedures, facilitating quick and easy contact with students.

In addition, PUM has an examination platform, i.e. Test Exam Center (https://egzamcet.pum.edu.pl) where students can pass final exams and interim test exams, including online. Zoom, a third party platform, is an additional tool that supports online learning, with the Discipline Council using it for its meetings. Moreover, the IT Department staff offer academic teachers the dysk.pum.edu.pl site for sharing educational resources (PUM's private file cloud).

In 2017, a project was implemented at the Department of Histology and Embryology of the PUM, whose objective was to improve the quality of course teaching.

With extensive professional and financial support from the Rector, classrooms could be modernized, so that students could learn the subject with the use of state-of-the-art engineering solutions. This improves the quality of education and makes it easier for students to accomplish the desired results as specified in the education standards for each faculty and course syllabus. This was the reason for building the very modern training and seminar room ("Najnowocześniejsi", 2017).

The new room accommodates 72 computer workstations for students. It can be used simultaneously by four workgroups, i.e. two seminar groups up to 36 members each. The new equipment has not only made the course more attractive, but also proceeding more smoothly. Every academic teacher has a computer at their workstation with a complete set of digital images of previously scanned histological preparations. Every student can also access these digital images on their computer, view them on screen, zoom in and out, move, or recognize details on a much larger surface than that visible under a microscope. Every teacher has a digital microscope at their disposal, which can be used to present a new conventional histological prepara- 
tion, stained with advanced methods, with the image displayed on students' screens.

According to the recommendations specified in the teaching standards, students can use a light microscope, including the use of immersion. However, it is important to emphasize that digitalization of histological preparations was certainly useful at the time of the pandemic, so that materials for students could be prepared, in addition to tissue and organ imaging and real-time presentation. With the system software, it was also possible to carry out interim tests, and practical and theoretical exams online.

Less than three years ago, when the Histology course was modernized and modified, nobody realized that this solution would enable and facilitate every form of online education in real time. Moreover, the Histology Unit has an ITest add-on for optimized knowledge testing and verification.

During the pandemic, in accordance with the general requirements, the necessary procedures were prepared at the School, specifying the rules for course teaching and options of assistance for academic teachers, available from the IT Department staff. Throughout the online learning process, Deans of the individual Faculties introduced rules concerning teaching time (specific number of hours defined in the teaching standards) to be spent on e-learning. If necessary, PUM is also prepared for deploying a blended learning model.

Online courses are not and certainly will not be as effective as on-site courses; however, with a number of implemented system utilities and commitment and cooperation between many people, courses can be effectively taught in the described manner.

\section{A Voice from the Jagiellonian University Medical College}

E-education delivered early in the pandemic period. The Jagiellonian University (JU) suspended the traditional classroom course system due to the SARS-CoV-2 coronavirus pandemic on 11 March, 2020. Three days later, the Dean's Authorities of the Faculty of Medicine issued their first communication, specifying the recommended forms of online courses. By the end of the semester, thirteen further communications were passed, detailing the University's guidelines regarding various aspects of education, such as forms of online lectures, online practice, or exams (Komunikaty Dziekana Wydziału Lekarskiego, 2020).

The pandemic struck at a point in time when the Jagiellonian University had already developed to a certain extent its e-learning infrastructure. 
Before the crisis, some faculties (such as the Faculty of Medicine) had already begun an intensive process of transferring lectures to electronic format. Nevertheless, other course models were only occasionally implemented online, and then primarily by e-learning enthusiasts. According to the estimations of the University's eLearning Centre, only $1 / 5$ of all academic teachers were using the online learning platform services in the academic year preceding the outbreak of the pandemic (Urbaniec, 2020). In these circumstances, many people faced the necessity to urgently acquire new online class teaching skills. The university's technical e-learning infrastructure guides (Centrum Zdalnego Nauczania, 2020), made available by the eLearning Centre, were helpful in achieving this goal. Moreover, minimum standards were prepared for the criteria required of the available e-learning forms. A good example can be the guidelines showing a properly delivered online lecture, including: splitting the recording into smaller sections, adding a voice-over narrative, or adding check questions (Komunikaty Dziekana Wydziału Lekarskiego, 2020).

The recommendations of the University's Authorities focused on using Microsoft suite products such as Teams (for real-time learning via teleconference), Forms (as a knowledge checking tool), and Power Point for recorded lectures. Alternatively, as an equivalent solution, the university's online learning platform Pegaz was also recommended, i.e. a Moodle-type (a popular education content management system) version adapted for the University's purposes, together with the integrated teleconferencing tool Big Blue Button (Komunikaty Dziekana Wydziału Lekarskiego, 2020).

At the time the pandemic broke out, the Department of Bioinformatics and Telemedicine of the Jagiellonian University Medical College (JU MC) had already had significant experience with the Pegaz platform, used in a blended learning scheme, as an electronic tool to support traditional learning and to deliver online lectures. It constituted a great help in the process of transition to a fully online scheme. The existing practice of sharing education resources, collecting reports, or delivering quizzes was extended with realtime student consultation sessions via a teleconferencing application. Popular e-learning tools available on Moodle such as Lesson, Discussion Forum or Wiki, made the learning process more interactive in asynchronous mode, beyond the rightfully criticized online learning system in which only a Power Point presentation would be provided. With certain additional utilities, such as CASUS (virtual patient platform), activities dedicated to skills typical for medical faculties, such as clinical reasoning, were offered to students (Hege et al., 2017). The body of resources available in CASUS was further extended with cases typical of SARS-CoV-2 infections (Hege et al., 2020). 
Lessons learned. Based on a survey concerning the use of online learning tools taken among students by the end of the summer semester of the academic year 2019/2020, carried out by the Competence Improvement Bureau of the JU, the decisions of the University's authorities have indeed been successfully implemented. In their questionnaires, students confirmed that Pegaz and Teams, as the two utilities recommended by the University, were used during nearly $90 \%$ of all classes (Biuro Doskonalenia Kompetencji, 2020a). In slightly less than $1 / 3$ of cases, practice materials were simply e-mailed to students (Biuro Doskonalenia Kompetencji, 2020a). A multiple and rapid increase in the use of publicly available clinical reasoning study aids in CASUS, a virtual patient system used by such units as the Department of Bioinformatics and Telemedicine of the JU MC, was observed compared to the equivalent period of the preceding year (Hege et al., 2020).

Students' reactions to the offered online courses were diverse and difficult to generalize at the university level, as teachers' commitment would also vary greatly. On the one hand, the extraordinary circumstances motivated people to work and any practical imperfections were easily forgiven by students, aware of the special situation. On the other hand, with time passing, some teachers' superficial approach to online classes was no longer acceptable, and students began to miss face-to-face contact with the class teacher.

Based on student interviews and feedback given as comments after practical sessions and at teacher council meetings at the end of the semester, the process of updating and structuring course materials was a positive effect the pandemic had on education, and it was necessary for the new class teaching format. When the presented contents were available to the broader public, teachers were motivated to improve the quality of the educational contents. Students appreciated some teachers' quick responses to their questions and issues. Coronavirus enforced a technological leap resulting from the use of teleconference tools in class; these utilities were rapidly becoming the primary teaching method.

There was a critical response to uploading huge volumes of information without sufficient comments to enable students to smoothly complete their tasks. The content uploading method and schedule was perceived as chaotic by students at some courses (uploads to various resources), or hard to follow (late night consultation, unrealistic deadlines). It is now a common belief among teachers and students alike that e-learning takes significantly more time compared to traditional courses (Biuro Doskonalenia Kompetencji, 2020b). The same activities that were possible in the classroom mode because the teacher imposed a certain rate of operation took much more 
time in asynchronous mode, requiring the students to be more motivated and capable of self-organization. As it could have been easily predicted earlier, online verification of knowledge and skills turned out to be a very difficult task in practice. There were numerous concerns about the solutions used, in terms of objectivity (including exposure to fraud), convenience, or personal data safety.

New academic year at the Jagiellonian University Medical College. The academic year 2020/2021 begins with the uncertainty and concerns about the possible worsening of the pandemic situation in autumn. Based on the decision of the University's Authorities, lectures continue to be delivered online only. For other education forms, however, there is a recommendation to return to traditional classroom meetings or to switch to the blended learning model. For reason of the requirement of minimum distance between class participants applicable during the pandemic, in some cases the meetings need to be divided into smaller groups. However, this does not increase the teachers' working hours and can only be compensated by switching certain other courses to the fully online scheme in larger groups. These circumstances encourage the development of new mixed arrangements. For example, teachers from the Department of Bioinformatics and Telemedicine are considering a division of students into smaller groups in laboratory rooms and teleconference rooms within the same unit's building, where the course would be coordinated by the course teacher. In this scheme, students follow their established schedules and meet on the university site, while the teacher can be present online in two rooms at the same time and offer traditional one-on-one consultation sessions if necessary during the class hours on-site (in the building). Within the online teaching framework, an increase of the proportion of synchronous elements in education is also planned (introductory conference before practical sessions, summing up previous practice), intertwined with asynchronous elements (project and task execution according to the provided instructions in a virtual environment).

\section{Final Conclusions and Challenges}

Even before the pandemic, it was known that the implementation of e-learning at a university involves a number of barriers (Kononowicz \& Hege, 2015). Some of them are real, while others are only illusions upheld on the basis of certain established traditions and resistance to the effort re- 
quired for change. The pandemic forced us all to leave our comfort zones and facilitated overcoming our mental barriers. The actual barriers occurring as a consequence of an inadequate infrastructure, teachers' know-how about effective online teaching, and legal regulations on e-education still remain but should be gradually eliminated.

Changes have to be implemented gradually, so that the otherwise reasonable tendency toward standardization of e-learning, with the objective of improving the quality of education, does not suppress e-learning enthusiasts' creativity. Some new ideas about transposing the methodological scheme of traditional learning into the online learning environment may seem convenient from the organizational perspective, yet they also neutralize certain features that are unique and exclusive of e-learning, such as: the use of specialized e-learning tools dedicated to the pursuit of certain precisely defined skills; independently creating knowledge in interactive virtual worlds; participation in the building online communities focused on studying together. Elimination of these solutions as a result of excessive regulation would be damaging to all stakeholders.

Even though one truly hopes that the pandemic crisis will pass soon, one should not be misled by the illusion that it will not happen again. Climate change, disasters caused by various sources, political and economic uncertainty, as well as the exponentially advancing technologies can force universities to quickly change their teaching and learning environments again. The experience gained during the SARS-CoV-2 epidemic should result in a better preparation for upcoming challenges.

\section{Acknowledgements}

The authors would like to thank Professor Irena Roterman-Konieczna and Doctor Eukasz Balcerzak from the Jagiellonian University Medical College for a valuable discussion about topics related to teaching university courses during the pandemic.

\section{R E F E R E N C E S}

Arroyo-Morales, M., Cantarero-Villanueva, I., Fernández-Lao, C., Guirao-Pińeyro, M., Castro-Martín, E., \& Díaz-Rodríguez, L. (2012). A blended learning approach to palpation and ultrasound imaging skills through supplementation of traditional classroom teaching with an e-learning package. Man Ther., $17(5), 474-478$. 
Biuro Doskonalenia Kompetencji. Centrum Wsparcia Dydaktyki Uniwersytetu Jagiellońskiego. (2020a). Barometr Satysfakcji Studenckiej - Ewaluacja Zdalnego Nauczania, 1-15.06.2020 https://jakosc.uj.edu.pl/aktualnosci/-/journal content/56_INSTANCE_B9Jc/1609422/145385501

Biuro Doskonalenia Kompetencji. Centrum Wsparcia Dydaktyki Uniwersytetu Jagiellońskiego. (2020b). Wyniki Badania Nauczycieli Akademickich, 115.06.2020 https://jakosc.uj.edu.pl/raport-zn-2020-pelny

Boczkowska, K., Bakalarski, P., Sviatoslav, M., \& Leszczyński, P.K. (2018) The importance of e-learning in professional improvement of emergency nurses. Critical CareInnovations, 1(1), 16-24.

Centrum Zdalnego Nauczania (2020). Przewodniki. https://przewodniki.uj.edu.pl

Hege, I., Kononowicz, A. A., Adler, M. (2017). A Clinical Reasoning Tool for Virtual Patients: Design-Based Research Study. JMIR Med Educ, 3(2).

Hege I., Sudacka M., Kononowicz A. A., Nonnenmann J., Banholzer J., Schelling J., Adler M., et al. (2020). Adaptation of an international virtual patient collection to the COVID-19 pandemic. GMS J Med Educ, 37(7), Doc92.

Komunikaty Dziekana Wydziału Lekarskiego UJ dotyczące zdalnych zajęć dydaktycznych. (2020), https://wl.cm.uj.edu.pl/zdalne-nauczanie

Kononowicz, A. A., \& Hege, I. (2015). Breaking down barriers to medical e-learning. Bio-Algorithms and Med-Systems, 11(2), 77-78.

Mitura, K. (2020) The impact of COVID-19 pandemic on critical care and surgical services availability. Critical CareInnovations, 3(2), 43-50. https://doi.org/ 10.32114/CCI.2020.3.2.43.50

Najnowocześniejsi. (2017). Najnowocześniejsi w Europie. Gazeta kurier24. https:// 24kurier.pl/aktualnosci/nauka/najnowoczesniejsi-w-europie/

Porter, J.E., Cant, R.P., \& Cooper, S.J. (2018). Rating teams' non-technical skills in the emergency department: A qualitative study of nurses' experience. International emergency nursing, 38, 15-20.

Roszak, M. (2019). Ocena przydatności e-learningu w kształceniu medycznym z zakresu patofizjologii. Wydawnictwo Naukowe Uniwersytetu Medycznego im. Karola Marcinkowskiego w Poznaniu.

Roszak, M., Mokwa-Tarnowska, I., \& Kołodziejczak, B. (2019). E-learning Competencies for University and College Staff w Universities in the Networked Society. Subtitle: Cultural Diversity and Digital Competences in Learning Communities. Series Title: Critical Studies of Education, 10(11), Springer, 185-200.

Rozporządzenie Ministra Nauki i Szkolnictwa Wyższego z dnia 18 maja 2020 r. zmieniające rozporządzenie w sprawie standardów kształcenia przygotowującego do wykonywania zawodu lekarza, lekarza dentysty, farmaceuty, pielęgniarki, położnej, diagnosty laboratoryjnego, fizjoterapeuty i ratownika medycznego. (2020). Dz.U. 2020 poz. 885. http://isap.sejm.gov.pl/isap.nsf/Doc Details.xsp?id=WDU20200000885 
Sobolewska, P., \& Pinet-Peralta, L.M. (2019). Use of the educational mobile applications by emergency medical services personnel. Critical Care Innovations, 2(2), 25-31.

Sowan, A.K., \& Idhail, J.A. (2014). Evaluation of an interactive web-based nursing course with streaming videos for medication administration skills. Int. J. Med. Inform., 83(8), 592-600.

Swift, A,. Efstathiou, N., \& Lameu, P. (2016). Is LabTutor a helpful component of the blended learning approach to biosciences? J Clin Nurs., 25(17-18), 2683-2693.

Urbaniec, J. (2020). Edukacja "Pandemiczna" czyli o kształceniu zdalnym na uczelniach, Forum Akademickie 05/2020, https://miesiecznik.forumakademickie. $\mathrm{pl}$ /czasopisma/fa-05-2020/edukacja-pandemiczna\%E2\%80\%A8czyli-o-kszta lceniu-zdalnym-na-uczelniach $\% \mathrm{E} 2 \% 80 \% \mathrm{~A} 9 /$

Wejnarski, A., Gajek Villebæk, P.A., \& Leszczyński, P.K. (2018). Prospective evaluation of interactive project of Emergency Medicine Exam with the use of multimedia computer devices. Critical Care Innovations, 1(1), 1-15.

Zarządzenie nr 36/2020 Rektora Uniwersytetu Przyrodniczo-Humanistycznego w Siedlcach z dnia 16 marca 2020 roku. (2020, Marzec, 16). Biuletyn Informacji Publicznej UPH. https://bip.ires.pl/gfx/ap/files/Prawo/ZR2020/ Z-036-20.pdf

Zarządzenie nr 80/2020 Rektora Uniwersytetu Przyrodniczo-Humanistycznego w Siedlcach z dnia 1 czerwca 2020 roku. (2020, Czerwiec 1). Biuletyn Informacji Publicznej UPH. https://bip.ires.pl/gfx/ap/files/Prawo/ZR2020/ Z-080-20.pdf

Zarządzenie nr 46/2020 Rektora Warszawskiego Uniwersytetu Medycznego z dnia 12.03.2020 r. (2020, Marzec 12). http://dokumenty.wum.edu.pl/?rodzaj=3

Zarządzenie nr 49/2020 Rektora Warszawskiego Uniwersytetu Medycznego z dnia 13.03.2020 r. (2020a, Marzec 13). http://dokumenty.wum.edu.pl/?rodzaj=3

Zarządzenie nr 50/2020 Rektora z dnia 13.03.2020 w sprawie powiększenia Uczelnianego Zespołu ds. Zagrożenia Koronawirusem. (2020b, Marzec 13). http://dokumenty.wum.edu.pl/?rodzaj=3

Zarządzenie nr 57/2020 Rektora Warszawskiego Uniwersytetu Medycznego z dnia 23.03.2020 r. (2020, Marzec 23). http://dokumenty.wum.edu.pl/?rodzaj=3

Zarządzenie nr 111/2020 Rektora Warszawskiego Uniwersytetu Medycznego z dnia 1 czerwca 2020 r. aktualizujace zarządzenie w sprawie przeciwdziałania rozprzestrzenianiu się wirusa SARS-CoV-2 wśród członków społeczności WUM. (2020, Czerwiec 1). http://dokumenty.wum.edu.pl/?rodzaj=3

Zarządzenie nr 142/2020 Rektora Warszawskiego Uniwersytetu Medycznego z dnia 6 lipca 2020 r. zmieniające zarządzenie aktualizujące zarządzenie Rektora nr 111/2020 z dnia 1 czerwca 2020 r. w sprawie przeciwdziałania rozprzestrzenianiu się wirusa SARS-CoV-2 wśród członków społeczności WUM. (2020, Lipiec 6). http://dokumenty.wum.edu.pl/?rodzaj=3 
Zarządzenie nr 150/2020 Rektora Warszawskiego Uniwersytetu Medycznego z dnia 10 lipca 2020 r. zmieniające zarządzenie aktualizujące Zarządzenie Rektora nr 111/2020 z dnia 1 czerwca 2020 r. w sprawie przeciwdziałania rozprzestrzenianiu się wirusa SARS-CoV-2 wśród członków społeczności WUM, z uwzględnieniem zmian, jak w zarządzeniu nr 142/2020 z dnia 6 lipca 2020 r. (2020, Lipiec 10). http://dokumenty.wum.edu.pl/?rodzaj=3

Zarządzenie nr 167/2020 Rektora Warszawskiego Uniwersytetu Medycznego z dnia 20 sierpnia 2020 r. w sprawie organizacji zajęć na studiach, studiach doktoranckich, w szkole doktorskiej, studiach podyplomowych, kursach i szkoleniach oraz organizacji zaliczeń i egzaminów, w semestrze zimowym roku akademickiego 2020/2021 w związku z epidemią COVID-19. (2020, Sierpień 20). http://dokumenty.wum.edu.pl/?rodzaj=3

Zarządzenie nr 170/2020 Rektora Warszawskiego Uniwersytetu Medycznego z dnia 26 sierpnia 2020 r. zmieniające zarządzenie aktualizujące Rektora nr 111/ 2020 z dnia 1 czerwca 2020 r. w sprawie przeciwdziałania rozprzestrzenianiu się wirusa SARS-CoV-2 wśród członków społeczności WUM, z uwzględnieniem zmian, jak w zarządzeniu nr 142 z dnia 6 lipca 2020 r., nr 150 z dnia 10 lipca 2020 r., nr 162 z dnia 12 sierpnia 2020 r. (2020, Sierpień 26). http://dokumenty.wum.edu.pl/?rodzaj=3

Zarządzenie nr 175/2020 Rektora Warszawskiego Uniwersytetu Medycznego z dnia 3 września 2020 r. zmieniające zarządzenie aktualizujące zarządzenie Rektora nr 111/2020 z dnia 1 czerwca 2020 r. w sprawie przeciwdziałania rozprzestrzenianiu się wirusa SARS-CoV-2 wśród członków społeczności WUM, z uwzględnieniem zmian, jak w zarządzeniu nr 142 z dnia 6 lipca 2020 r., nr 150 z dnia 10 lipca 2020 r., nr 162 z dnia 12 sierpnia 2020 r., nr 170 z dnia 26 sierpnia 2020 r. (2020, Wrzesień 3). http://dokumenty.wum.edu.pl/ ?rodzaj=3

Zarządzenie Rektora Wyższej Szkoły Rehabilitacji z siedzibą w Warszawie z dnia 11 marca 2020 roku W sprawie: Przeciwdziałania rozprzestrzenianiu się wirusa SARS COV-2 (COVID-19) wśród członków społeczności Uczelni. (2020, Marzec 11). WSR. https://www.wsr.edu.pl/akty-prawne/send/15akty-prawne/232-zarzadzenie-rektora-wyzszej-szkoly-rehabilitacji-z-siedziba -w-warszawie-z-dnia-11-marca-2020-roku

Zarządzenie Rektora Wyższej Szkoły Rehabilitacji z siedzibą w Warszawie z dnia 27 maja 2020 r. w sprawie: trybu przeprowadzania egzaminów i zaliczeń w okresie zawieszenia zajęć dydaktycznych z powodu zagrożenia COVID-19. (2020, Maj 27). https://www.wsr.edu.pl/images/stories/20200527_Zarzadze nie_Rektora_z_dnia_27_maja_-_egzaminy_i_zaliczenia_on-line.pdf

Zasady weryfikacji osiągniętych efektów uczenia się z wykorzystaniem technologii informatycznych zapewniających kontrolę ich przebiegu i rejestrację. (2020). Strefa Studenta WSR. http://www.strefastudenta.wsr.edu.pl/sesja-egzamina cyjna/send/74-sesja-egzaminacyjna/1988-zasady-weryfikacji-efektow-uczeniasie-w-e-learningu 